Artikel Penelitian

\title{
Formulasi Nikstamal Jagung, Tempe, dan Sayuran Terfermentasi dalam Perolehan Pasta Fortifikan sebagai Sumber Asam Folat Alami
}

\section{Formulation Nixtamalized Corn, Tempeh, and Fermented Vegetables for Producing Fortificant Paste as Natural Follic Acid Source}

Agustine Susilowati ${ }^{\star}$, Yati Maryati, Puspa Dewi Nariij Lotulung, Aspiyanto

Pusat Penelitian Kimia , Lembaga IImu Pengetahuan Indonesia, Kawasan Pusat Penelitian IImu Pengetahuan dan Teknologi, Serpong, Tangerang Selatan - 15314, Banten

*Korespodensi dengan penulis (agustine_1408@yahoo.co.id)

Artikel ini dikirim pada tanggal 09 April 2018 dan dinyatakan diterima tanggal 28 Mei 2018. Artikel ini juga dipublikasi secara online melalui www.jatp.ift.or.id. Hak cipta dilindungi undang-undang. Dilarang diperbanyak untuk tujuan komersial.

Diproduksi oleh Indonesian Food Technologists ${ }^{\circledR}(C 2018$

\begin{abstract}
Abstrak
Penelitian ini bertujuan untuk melakukan formulasi dalam pembuatan pasta fortifikan asam folat alami yang terdiri dari campuran tempe (kedelai dan kacang hijau), sayuran terfermentasi (brokoli dan bayam), dengan nikstamal jagung kuning dan jagung putih jenis gigi kuda guna mengetahui rasio terbaik campuran ketiga bahan tersebut terhadap konsentrasi asam folat dan identifikasi monomer-monomernya. Rangkaian proses fermentasi tempe dan sayuran masing-masing dilakukan menggunakan Rhizopus oligosporus strain $\mathrm{C} 1$ dan kultur Kombucha, serta nikstamalisasi jagung dilakukan dengan menggunakan $\mathrm{Ca}(\mathrm{OH})_{2}$. Formulasi dilakukan dengan mengatur rasio campuran tempe plus sayuran terfermentasi dan nikstamal jagung pada rasio 1:1, 1:2, 1:3, 1:4, dan 1:5. Analisis dilakukan terhadap protein terlarut, total padatan, gula reduksi, total gula dan asam folat. Identifikasi asam folat dan asam glutamat dilakukan melalui LC-MS. Penelitian ini berhasil untuk menentukan rasio terbaik guna menghasilkan asam folat tertinggi serta berhasil mengidentifikasi monomer asam folat dan asam glutamat pasta fortifikan asam folat. Kesimpulannya, formulasi pasta fortifikan asam folat terbaik dapat dicapai pada kombinasi pasta campuran tempe plus sayuran terfermentasi dengan nikstamal jagung pada rasio 1:5.
\end{abstract}

Kata kunci : asam folat, jagung, tempe, sayuran, pasta, formulasi.

\begin{abstract}
This research was done to obtain the highest concentration of folic acid and the monomer identification on paste formulation with various additions of natural folic acid source from tempeh (G. soyae and mung beans/P. radiatus), and fermented broccoli, and fermented spinach with both nixtamalized yellow corn and white corn (Zea mays $L$. var. indentata). The research was conducted through a series of tempe and vegetable fermentation process using Rhizopus oligosporus strain $\mathrm{C} 1$ and Kombucha culture, and nixtamalization of corn was done using $\mathrm{Ca}(\mathrm{OH})_{2}$. Ratio was set at 1:1, 1:2, 1:3, 1:4 and 1:5 of mixture paste of tempeh \& fermented vegetables to nixtamalized corn, respectively. The result of experiment showed that nixtamalized corn ratio resulted in the increase in folic acid, total solids, and decreased dissolved protein, total sugars and reducing sugars. As conclusion, based on the best concentration of folic acid, optimization of formulation was achieved at combination between mixture of mung beans tempeh \& fermented broccoli and a 1:5 ratio of corn.
\end{abstract}

Keywords : folic acid, corn, tempeh, vegetables, paste, formulation

$\cdot 1 \cdot 1 \cdot 1 \cdot 1 \cdot 1 \cdot$

\section{Pendahuluan}

Proses penggalian potensi bahan pangan alam untuk memperoleh asam folat merupakan salah satu upaya untuk mencerdaskan bangsa melalui konsumsi 'pangan pintar'. Pangan pintar diartikan sebagai bentuk nyata makanan dengan nutrisi spesifik untuk mendukung kecerdasan anak selagi dalam kandungan maupun pada masa pertumbuhan sebagai anak-anak (balita) (Susilowati et al., 2015). Sumber utama pada pangan pintar dipilih dari komponen pangan yang berpengaruh terhadap perkembangan kecerdasan diantaranya adalah asam folat (Ural, 2008).
Fortifikan asam folat alami guna meningkatkan kandungan asam folat alami, dapat diperoleh dari kedelai (Glicinia soyae), kacang hijau ( $P$. radiatus), brokoli (Brassica oleracea) dan bayam (Amaranthus sp.) yang terfermentasi dan nikstamal jagung gigi kuda (Zea mays L. var identata). Bahan-bahan tersebut merupakan komoditas yang dapat diandalkan dalam menghasilkan asam folat melalui melalui proses fermentasi dan nikstamalisasi (proses pemasakan biji jagung yang lazimnya dengan menggunakan larutan kapur) dalam rangka meningkatkan kandungan asam folatnya dan dapat diaplikasikan pada berbagai jenis makanan (Susilowati et al., 2015). 
Kacang-kacangan terfermentasi oleh kapang Rhizopus sp baik tunggal (Rhizopus oligosporus) maupun campuran ( $R$. oligosporus, $R$. stolonifer, $R$. oryzeae dan Rhizopus sp lainnya) sebagai inokulum campuran dapat menghasilkan tempe yang telah dikenal sejak lama sebagai sumber protein nabati (Syarief et al., 1999). Peranannya sebagai sumber asam folat, menjadikan tempe sebagai salah komponen utama dalam formulasi pangan pintar (smart food) selain sumber asam folat lainnya seperti brokoli dan bayam yang terfermentasi serta nikstamal jagung (Susilowati et al., 2015). Perpaduan tempe dengan sayuran terfermentasi tersebut dapat digunakan untuk menghasilkan produk pasta yang berfungsi sebagai sumber asam folat alami (Susilowati et al., 2015).

Penelitian terdahulu telah berhasil membuktikan bahwa fermentasi brokoli (Brassica oleracea) dan bayam (Amaranthus sp.) oleh kultur kombucha dapat memperoleh biomasa yang kaya akan asam folat (Susilowati et al., 2015). Proses ini adalah pengembangan pangan fermentasi yang melibatkan peranan enzim dihydrofolate synthase (DHFS) dan enzim folypolyglutamate synthase (FPGS) yang masingmasing membentuk dihydrofolate dan polyglutamat folate, suatu bentuk derivate asam folat (de CrécyLagard et al., 2007), dan ternyata proses ini hanya terjadi pada tumbuhan dan mikroba (Hauser and Macreadie, 2006). Kultur kombucha mengandung bakteri asam asetat yaitu Acetobacter xylinum dan yeast yaitu Saccharomyces cereviseae, Saccharomyces ludwigii, S. bisporus, Zygosaccharomyces $\mathrm{sp}$ dan beberapa jenis khamir (Torolupsis sp) (Malbaša et al., 2008) yang diduga dapat mendegradasi polifenol dan asam-asam amino pada brokoli dan bayam. Diketahui terdapat lebih dari 8 jenis enzim spesifik dari tanaman yang berperan dalam sintesis ini (Quinlivan et al., 2003). Modifikasi proses fermentasi dapat dilakukan melalui berbagai jenis variasi perlakuan seperti pengayaan sukrosa dan variasi lingkungan (waktu fermentasi dan konsentrasi kultur), dan suhu fermentasi (Susilowati et al., 2017). Substrat brokoli dan bayam telah terbukti mampu menghasilkan asam folat, seperti halnya pada fermentasi daun teh (hijau) yang meningkatkan kandungan L-theanine (EthylL-glutamine atau L-Glutamic acid $\gamma$-(ethylamide) dan total polifenolnya (Susilowati et al., 2010).<smiles>Nc1nc(O)c2nc(CNc3ccc(C(=O)N[C@@H](CCC(=O)O)C(=O)O)cc3)cnc2n1</smiles>

Figur 1. Rumus Bangun Asam folat

Proses fortifikasi nikstamal jagung dinilai mampu meningkatkan dan menahan kehilangan asam folat
(Figur 1) selama proses formulasi pasta. Proses nikstamalisasi ini pada umumnya dilakukan dengan cara perendaman biji jagung dalam $\mathrm{Ca}(\mathrm{OH})_{2}$ yang selanjutnya dilakukan perebusan sebagai upaya untuk memperoleh nikstamal dengan sifat fisiko kimia lebih baik, memperbaiki rasa (taste) dan aroma (flavour), mempermudah gelatinisasi pati dan penyerapan air serta mengeluarkan sebagian lembaga dan perikarp dari bji jagung (Rooney and Serna-Saldivar, 1987). Beberapa proses modifikasi guna memperoleh nikstamal jagung kaya asam folat, dapat dilakukan seperti perebusan langsung tanpa penyaringan dan proses penirisan dilakukan pada suhu ruang dinilai dapat mengurangi kehilangan asam folat (Susilowati et al., 2015). Dalam rangka pembuatan pasta yang kaya akan asam folat, maka penelitian ini bertujuan untuk memformulasikan ketiga macam bahan makanan, yaitu tempe, brokoli dan bayam yang terfermentasi, serta nikstamal jagung guna mendapatkan rasio yang terbaik untuk memperoleh pasta fortifikan.

\section{Materi dan Metode \\ Materi}

Bahan utama dalam penelitian ini adalah kedelai, kacang hijau, inokulum Rhizopus oligosporus strain $\mathrm{C}_{1}$ (didapat dari Pusat Penelitian Kimia-LIPI), brokoli dan bayam dari pasar setempat, kultur kombucha (diperoleh dari Pusat Penelitian Kimia-LIPI), jagung kuning dan jagung putih jenis gigi kuda (Zea mays $\mathrm{L}$. var identata) dari sentra perkebunan setempat (Tangerang selatan), sukrosa dan bahan kimia untuk proses dan analisis. Peralatan proses yang digunakan adalah peralatan mikrobiologi yaitu sistem laminar flow, lemari fermentasi, inkubator; peralatan nikstamalisasi, blender dan homogenizer. Instrumen analisis utama adalah spektrofotometer (UV), LC-MS (Mariner Biospectrometry) dengan LC (Hitachi L 6200) dan microfiltrasi sel berpengaduk menggunakan membran mikrofiltrasi 0,15 $\mu \mathrm{m}$.

\section{Metode}

Penelitian dilakukan dengan melakukan fermentasi kacang kedelai dan kacang hijau menggunakan inokulum Rhizopus oligosporus strain $\mathrm{C}_{1}$, fermentasi sayuran yaitu brokoli dan bayam menggunakan inokulum sayuran dari kultur kombucha dan proses nikstamalisasi jagung kuning \& jagung putih jenis gigi kuda. Pasta fortifikan dibuat dari pasta campuran tempe dengan sayuran terfermentasi pada rasio 1:1 yang difortifikasikan pada nikstamal jagung kuning dan nikstamal jagung putih pada berbagai macam rasio, yaitu 1:1, 1:2, 1:3, 1:4 dan 1:5. Analisis dilakukan terhadap protein terlarut (metode Lowry) (Lowry, et al., 1951) total padatan (metode Gravimetri), gula reduksi (Somogyi-Nelson), total gula (metode Fenol Sulfat) (Dubois et al., 1956) dan asam folat (spektrofotometri UV-VIS) (Ruengsitagoon dan Hattanat, 2012). Identifikasi asam folat dan asam glutamat 
Tabel 1. Komposisi bahan dalam formulasi pasta fortifikan asam folat alami.

\begin{tabular}{llccccc}
\hline & \multirow{2}{*}{ Jenis Bahan } & \multicolumn{4}{c}{ Komponen } \\
\cline { 3 - 6 } & & $\begin{array}{c}\text { Asam Folat } \\
(\mu \mathrm{g} / \mathrm{ml})\end{array}$ & $\begin{array}{c}\text { Total Padatan } \\
(\%)\end{array}$ & $\begin{array}{c}\text { Protein terlarut } \\
(\mathrm{mg} / \mathrm{ml})\end{array}$ & $\begin{array}{c}\text { Total gula } \\
(\mu \mathrm{g} / \mathrm{ml})\end{array}$ & $\begin{array}{c}\text { Gula reduksi } \\
(\mathrm{mg} / \mathrm{ml})\end{array}$ \\
\hline 1. & Pasta tempe kedelai \& brokoli & $514,26 \pm 10,26$ & $23,36 \pm 0,13$ & $2,11 \pm 0,012$ & $3435,60 \pm 59,26$ & $7,9 \pm 0,23$ \\
2. & Pasta tempe k. hijau \& brokoli & $391,70 \pm 8,13$ & $22,42 \pm 0,17$ & $0,46 \pm 0,001$ & $5440,15 \pm 64,29$ & $14,5 \pm 0,54$ \\
3. & Pasta tempe kedelai \& bayam & $514,07 \pm 10,56$ & $23,03 \pm 0,15$ & $2,26 \pm 0,009$ & $2930,3 \pm 45,17$ & $5,0 \pm 0,13$ \\
4. & Pasta tempe k. hijau \& bayam & $347,04 \pm 8,25$ & $22,34 \pm 1,19$ & $1,25 \pm 0,013$ & $3688,64 \pm 48,23$ & $18,7 \pm 0,53$ \\
5. & Nikstamal Jagung kuning & $466,81 \pm 8,10$ & $43,78 \pm 1,14$ & $0,03 \pm 0,001$ & $146,84 \pm 8,26$ & $1,24 \pm 0,03$ \\
6. & Nikstamal Jagung putih & $506,74 \pm 9,19$ & $47,06 \pm 1,03$ & $0,04 \pm 0,002$ & $200,81 \pm 7,48$ & $3,15 \pm 0,03$ \\
\hline
\end{tabular}

dilakukan melalui LC-MS (Mariner Biospectrometry, LC dengan Hitachi L 6200) (Eichhorn and Knepper, 2001).

\section{Proses fermentasi kacang-kacangan (tempe)}

Sejumlah kacang kedelai (Glycine soja) dan kacang hijau ( $P$. radiatus) disortasi, dicuci bersih, direbus selama 30-45 menit selanjutnya didinginkan, direndam dalam air semalam pada $\mathrm{pH}$ 5. Keesokannya dikupas, dicuci bersih, ditiriskan dan masing-masing kacang diinokulasi dengan inokulum tempe Rhizopus oligosporus strain $\mathrm{C}_{1}$ pada konsentrasi $0,2 \%(\mathrm{~b} / \mathrm{b})$, dibungkus dalam plastik berlubang dan diinkubasi selama 24 jam pada suhu ruang $\left(28-30^{\circ} \mathrm{C}\right.$ ) (Susilowati et al., 2015).

Proses fermentasi brokoli dan bayam.

Proses blansing dilakukan pada brokoli dan bayam dengan suhu $80^{\circ} \mathrm{C}$ masing-masing selama 5 dan 15 menit, selanjutnya dilumatkan pada rasio 1 bagian sayuran dan 4 bagian air sehingga diperoleh bubur sebagai substrat selanjutnya dibubuhi dengan masingmasing inokulum sayur sesuai dengan jenis sayur (Susilowati et al., 2015) sebanyak 15\% (v/b bubur sayur) dan sukrosa $10 \%$ (b/b bubur sayur) selanjutnya disimpan pada wadah tertutup dengan aerasi (kain kassa) pada ruang gelap dan suhu ruang masing-masing selama 3 dan 6 hari. Seluruh pekerjaan dilakukan secara aseptis. Perolehan biomasa adalah suspensi sayuran terfermentasi.

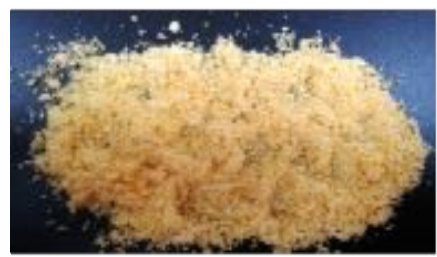

(a)

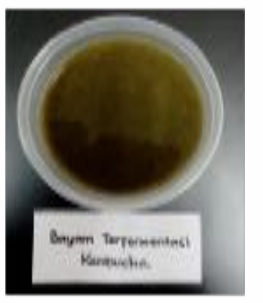

(c)

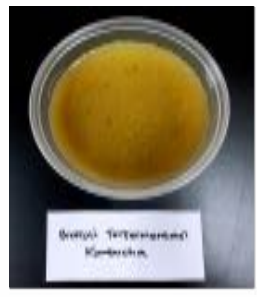

(d)

Proses nikstamalisasi jagung

Sejumlah jagung kuning dan jagung putih jenis gigi kuda dicuci, direndam dalam air dengan perbandingan 1 bagian jagung dengan 4 bagian air. Pada rendaman jagung kuning dan jagung putih selanjutnya dibubuhkan $\mathrm{Ca}(\mathrm{OH})_{2}$ masing-masing $20 \%$ dan $30 \%$ (b/b protein terlarut jagung) dan direbus masing-masing selama 60 dan 30 menit pada suhu $90^{\circ} \mathrm{C}$ didinginkan, dicuci untuk menghilangkan sisa alkali dan ditiriskan. Biji jagung (nikstamal) selanjutnya digrinder/digiling dan diayak lolos 60 mesh sehingga dihasilkan nikstamal jagung siap digunakan (Susilowati et al., 2015).

\section{Proses pencampuran dan emulsifikasi}

Proses pembuatan pasta campuran tempe dan sayuran terfermentasi dilakukan dengan mencampurkan ke dua bahan tersebut pada rasio 1:1, selanjutnya dihomogenisasi pada kecepatan $8000 \mathrm{rpm}$ selama 30 menit sehingga dihasilkan pasta campuran tempe \& sayuran fermentasi. Nikstamal jagung selanjutnya dibubuhkan pada pasta campuran tempe dan sayuran fermentasi pada berbagai rasio, dihomogenisasi pada kecepatan $8000 \mathrm{rpm}$ selama 30 menit sehingga diperoleh pasta fortifikan (Susilowati et al., 2015).

\section{Hasil dan Pembahasan}

Karakteristik bahan

Formulasi pasta fortifikan terdiri dari kombinasi nikstamal jagung, tempe dan sayuran terfermentasi yang

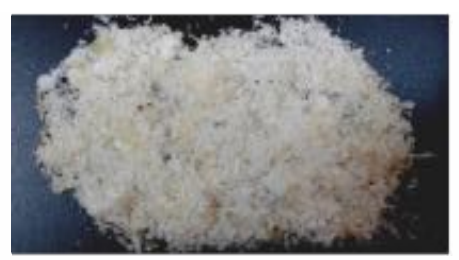

(b)

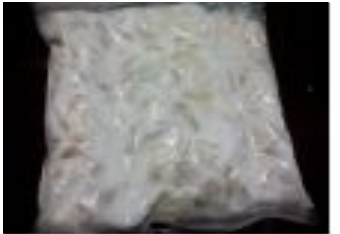

(e)

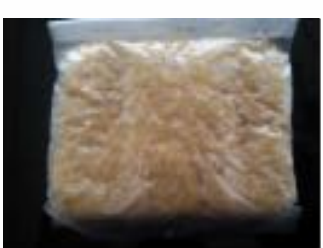

(f)

Figur 2. (a) nikstamal jagung kuning; (b) nikstamal jagung putih; (c) bayam terfermentasi; (d) brokoli terfermentasi; (e) tempe kedelai dan (f) tempe kacang hijau. 
dilakukan guna meningkatkan komposisi nutrisinya terutama asam folat. Tabel 1 memperlihatkan komposisi keseluruhan bahan, sedangkan Figur 2a, 2b, 2c, 2d dan 2 e masing-masing memperlihatkan nikstamal jagung kuning, nikstamal jagung putih, bayam terfermentasi , brokoli terfermentasi, tempe kedelai dan tempe kacang hijau.

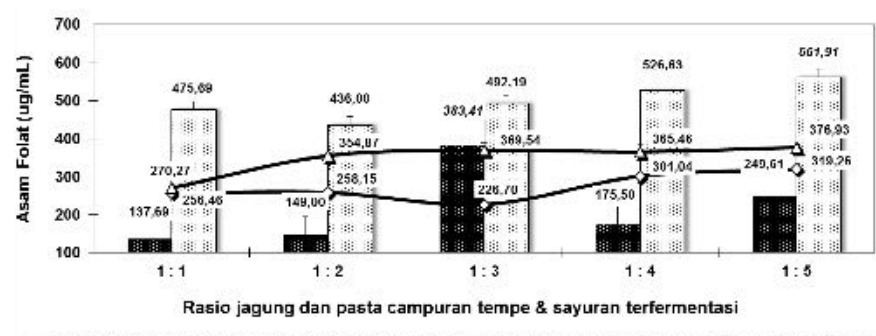

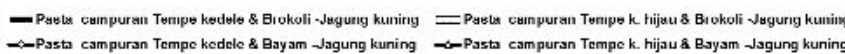

(a)

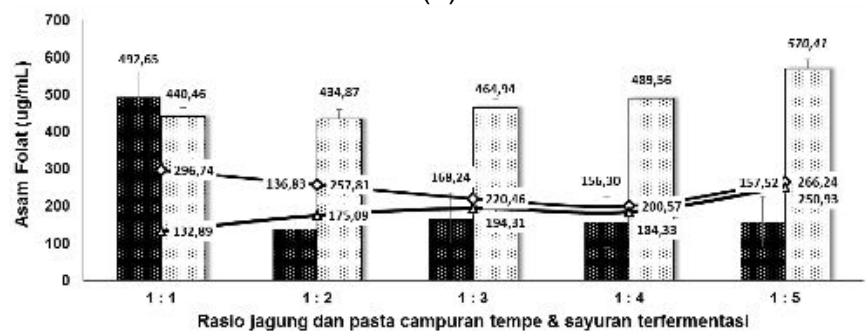

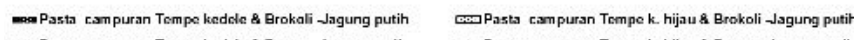
- O-Pasta campuran Tempo kedde \& Bayam Jagung putih \$-Pasta campuran Tempe k. hijau \& Bayam Jagung putih

(b)

Figur 3. Hubungan antara nikstamal jagung kuning (a) dan nikstamal jagung putih (b), jenis pasta tempe \& sayuran dan rasio antara keduanya terhadap perolehan asam folat pada pasta fortifikan sebagai sumber asam folat alami untuk 'pangan pintar'.

Pasta tempe kedelai brokoli dan tempe kedelai bayam menunjukkan konsentrasi asam folat yang lebih tinggi masing-masing sebesar 514,26 dan 514,07 $\mu \mathrm{g} / \mathrm{ml}$ dibandingkan dengan tempe kacang hijau baik dengan kombinasi brokoli maupun bayam masing-masing sebesar 391,70 dan 347,04 $\mu \mathrm{g} / \mathrm{ml}$. Hal ini menunjukkan bahwa enzim protease $R$. oligosporus strain $\mathrm{C}_{1}$ lebih mampu mendegradasi protein kedelai dibandingkan kacang hijau. Hal ini juga terlihat pada konsentrasi protein terlarut pasta tempe kedelai yang lebih tinggi dibandingkan dengan tempe kacang hijau baik dengan brokoli maupun bayam. Asam folat adalah derivat asam glutamat (pteroyl - L - glutamic acid / pteroyl - L glutamate) terhitung sebagai protein terlarut. Terhadap komponen yang lain pada keseluruhannya adalah hasil dari proses-proses yang menyertai dimana optimisasi proses dilakukan berdasarkan perolehan asam folat tertinggi (Susilowati et al., 2015).

Pengaruh formulasi terhadap komposisi asam folat

Proses pencampuran dan emulsifikasi pada rasio nikstamal jagung dan pasta campuran tempe dan sayuran terfermentasi pada berbagai rasio, menghasilkan pasta fortifikan dengan konsentrasi asam folat cenderung meningkat pada nikstamal jagung kuning, namun berfluktuatif pada nikstamal jagung putih sejalan dengan peningkatan nikstamal jagung. Penggunaan bayam dapat menghasilkan asam folat yang lebih tinggi dibandingkan dengan brokoli pada kedua jenis jagung seperti ditunjukkan pada Figur $3 a$ dan Figur 3b.

Perbedaan perolehan asam folat ini selain disebabkan konsentrasi masing-masing bahan awal juga oleh kontribusi nikstamal jagung. Semakin tinggi kontribusi nikstamal jagung akan meningkatkan asam folat, meskipun demikian terjadi optimasi asam folat yang diikuti dengan penurunan asam folat sampai rasio tertinggi (1:5). Beberapa faktor diduga berpengaruh diantaranya adalah keseluruhan perlakuan proses (homogenisasi) dan ketidakstabilan asam folat. Dari keseluruhan perlakuan proses, optimisasi asam folat dicapai pada kombinasi perlakuan campuran tempe kacang hijau dengan brokoli baik pada nikstamal jagung kuning maupun jagung putih pada rasio 1:5 masingmasing menghasilkan pasta fortifikan sebesar 561,91 dan 570,41 $\mu \mathrm{g} / \mathrm{ml}$. Pada kondisi ini, penambahan nikstamal jagung kuning dan nikstamal jagung putih terbukti meningkatkan asam folat pasta fortifikan masing-masing sebesar 43,45 dan 45,62\% dibandingkan dengan asam folat awal pasta campuran tempe kacang hijau dan brokoli terfermentasi awal masing-masing dari 391,70 $\mu \mathrm{g} / \mathrm{ml}$.

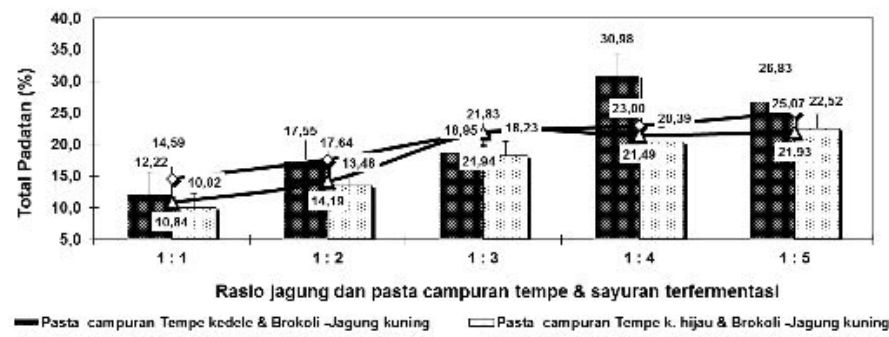

-Pasta campuran Tempe kedele \& Brokoli Jagung kuning CPasta campuran Tempe k. hijsu \& Brokoli Jagung kuning (a)

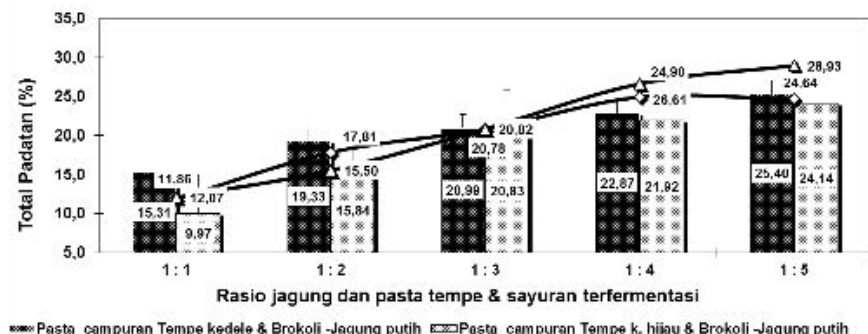

- Pasta campuran Tempe kedele a Brokoli Jagung puth Es Pasta campuran Tempo K. hiknu \& Brokoli Jagung puth

(b)

Figur 4. Hubungan antara nikstamal jagung kuning (a) dan nikstamal jagung putih (b), jenis pasta tempe \& sayuran dan rasio antara keduanya terhadap perolehan total padatan pada pasta fortifikan sebagai sumber asam folat alami untuk 'pangan pintar'.

Total padatan adalah akumulasi seluruh komponen pasta baik terlarut maupun tidak terlarut. Formulasi dengan pembubuhan nikstamal jagung yang semakin meningkat akan meningkatkan total padatan pasta fortifikan seperti ditunjukkan pada Figur $5 \mathrm{a}$ dan $5 \mathrm{~b}$. Nikstamal jagung kuning dan nikstamal jagung putih menunjukkan peningkatan sampai rasio tertinggi (1:5) 
dimana optimasi masing-masing dicapai dengan pembubuhan pasta campuran tempe kedelai dan brokoli terfermentasi $(26,83 \%)$ dan pasta campuran tempe kacang hijau dan bayam terfementasi (28,93\%). Pada kondisi ini, penambahan nikstamal jagung kuning dan nikstamal jagung putih dapat meningkatkan total padatan pasta fortifikan masing-masing sebesar 38,72 dan $38,52 \%$ dibandingkan dengan total padatan awal pasta campuran tempe kedelai \& brokoli terfermentasi dan pasta campuran tempe kacang hijau dan bayam terfementasi awal masing-masing dari 23.36 dan $22,34 \%$. Peningkatan ini disebabkan perbedaan total padatan antara kedua komponen yang cukup besar sehingga massa menjadi lebih kental dan padat, selain dari faktor emulsifikasi, yaitu faktor keterikatan partikel yang diduga berpengaruh pada perolehan total padatan. Semakin kecil partikel akan semakin luas tegangan permukaannya sehingga dapat semakin terikat erat dan meningkatkan total padatan keseluruhan massa pasta fortifikan.

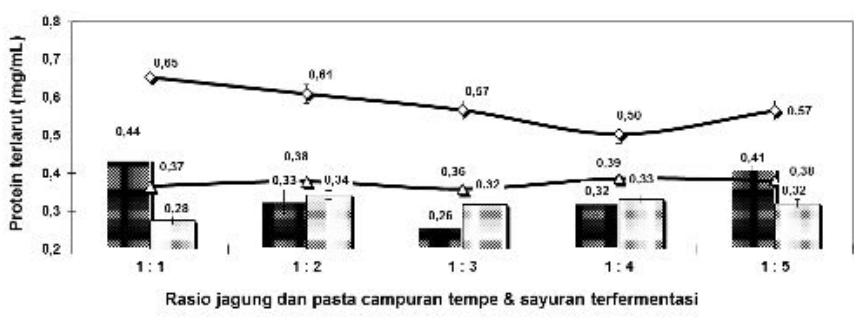

- Pusta campuran Tempe kedelete \& Brokoli Jayuung kuninga ᄃPustu campuran Tempe k. hijau \& Biokoli Jagung kuringy (a)

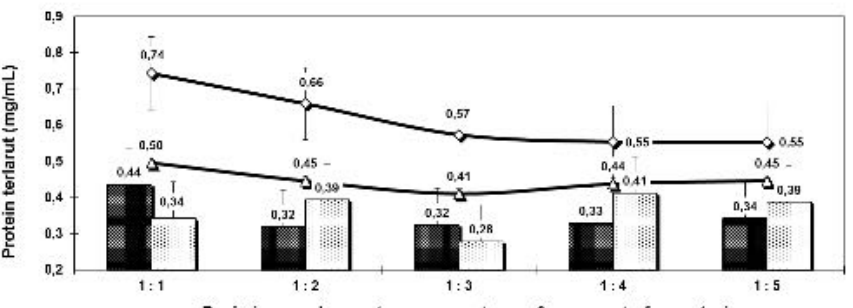

Rasio jagung dan pasta campuran tempe \& sayuran terformas

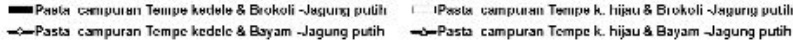
(b)

Figur 5. Hubungan antara nikstamal jagung kuning (a) dan nikstamal jagung putih (b), jenis pasta tempe \& sayuran dan rasio antara keduanya terhadap perolehan protein terlarut pada pasta fortifikan sebagai sumber asam folat alami untuk 'pangan pintar'.

Pengaruh formulasi terhadap komposisi protein terlarut

Protein terlarut menjadi acuan dalam formulasi ini oleh karena formulasi dilakukan berbasis asam folat yang keseluruhan prosesnya dilakukan dengan antisipasi kehilangan asam folat secara minimal. Asam folat merupakan bagian dari protein terlarut oleh struktur kimianya yang terdiri dari PABA (para amino benzoat), asam glutamat dan pteridin (Vora et al., 2002). Pembubuhan nikstamal jagung kuning dalam pasta campuran tempe kedelai maupun tempe kacang hijau pada bayam tefermentasi menghasilkan pasta fortifikan dengan protein terlarut yang lebih tinggi dari pada keseluruhan perlakuan lainnya, hal yang sama juga ditunjukkan pada nikstamal jagung putih. Pada perlakuan ini protein terlarut cenderung menurun sejalan dengan meningkatnya pembubuhan nikstamal jagung. Penurunan ini diduga disebabkan daya ikat protein yang semakin besar oleh nikstamal jagung sehingga tidak larut dalam massa fortifikan. Hal yang berbeda tampak pada pemberian nikstamal jagung pada pasta tempe kedelai/tempe kacang hijau dan brokoli terfermentasi yang cenderung berfluktuatif namun mempunyai tren yang sama seperti ditunjukkan pada Figur 5a dan Figur $5 b$.

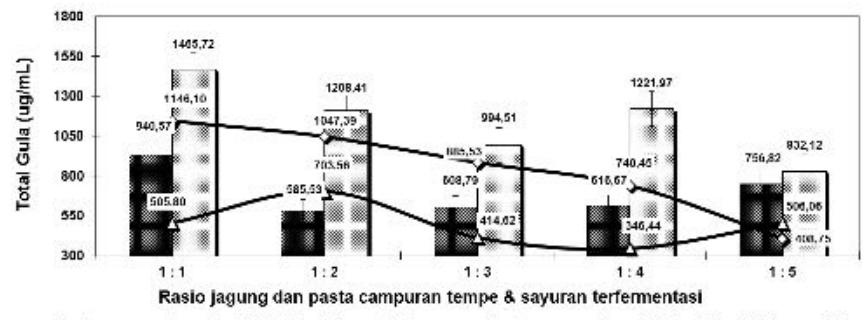

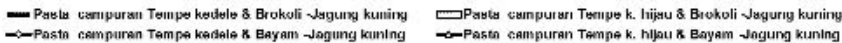

(a)

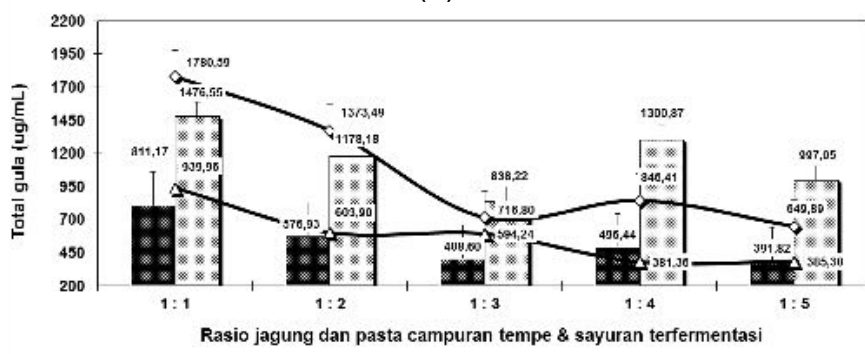

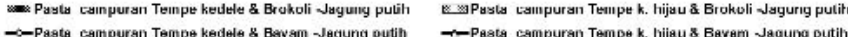
(b)

Figur 6. Hubungan antara nikstamal jagung kuning (a) dan nikstamal jagung putih (b), jenis pasta tempe \& sayuran dan rasio antara keduanya terhadap perolehan total gula pada pasta fortifikan sebagai sumber asam folat alami untuk 'pangan pintar'.

Secara keseluruhan rasio $1: 1$ adalah rasio formulasi yang menghasilkan protein terlarut terbaik pada keseluruhan perlakuan. Optimisasi formulasi terhadap protein terlarut dicapai pada kombinasi pasta campuran tempe kedelai \& bayam terfermentasi baik dengan nikstamal jagung kuning maupun nikstamal jagung putih pada rasio 1:1 masing-masing sebesar 0,65 dan $0,74 \mathrm{mg} / \mathrm{ml}$. Pada kondisi ini, penambahan nikstamal jagung kuning dan nikstamal jagung putih dapat menurunkan protein terlarut pasta fortifikan masing-masing sebesar 71,24 dan $67,26 \%$ dibandingkan dengan protein terlarut awal pasta campuran tempe kedelai dan bayam terfermentasi awal sebesar 2,26 $\mathrm{mg} / \mathrm{ml}$.

Pengaruh formulasi terhadap komposisi total gula

Total gula pasta fortifikan merupakan gambaran keseluruhan polisakarida (karbohidrat) sebagai sumber energi seperti pada umumnya sifat fungsional jagung. Semakin meningkatnya rasio nikstamal jagung pada pasta campuran tempe \& sayuran terfermentasi akan 
menurunkan total gula seperti ditunjukkan pada Figur $7 a$ dan 7b. Penurunan total gula diduga disebabkan terjadinya penguraian gula kedalam dua jenis bahan oleh metabolit yang dihasilkan oleh sayuran terfermentasi (asam-asam organik) dan akumulasinya dengan komponen sayuran terfermentasi (polifenol). Diketahui, sayuran terfermentasi oleh kultur kombucha menghasilkan sejumlah asam-asam organik terhitung sebagai total asam dengan kisaran tingkat keasaman $(\mathrm{pH})$ 2-4 dan polifenol yang cukup tinggi (Susilowati dan Melanie, 2017). Semakin tinggi konsentrasi pembubuhan nikstamal jagung, menyebabkan semakin tingginya penguraian karbohidrat sehingga menurunkan total gula. Optimisasi proses formulasi berdasarkan tingginya total gula sebagai sumber energi dicapai pada kombinasi perlakuan jagung kuning dan jagung putih masing-masing dengan pasta campuran tempe kacang hijau plus brokoli terfermentasi dan pasta campuran tempe kedelai plus bayam terfermentasi terfermentasi pada rasio 1:1 menghasilkan pasta fortifikan dengan total gula sebesar 1456,72 dan 1780,59 $\mu \mathrm{g} / \mathrm{ml}$. Pada kondisi ini, penambahan nikstamal jagung kuning dan nikstamal jagung putih dapat menurunkan total gula pasta fortifikan masing-masing sebesar 73,22 dan $39,23 \%$ dibandingkan dengan total gula awal pasta campuran tempe kacang hijau plus brokoli terfermentasi dan pasta campuran tempe kedelai plus bayam terfermentasi awal sebesar 5440,15 dan 2930,3 $\mu \mathrm{g} / \mathrm{ml}$.

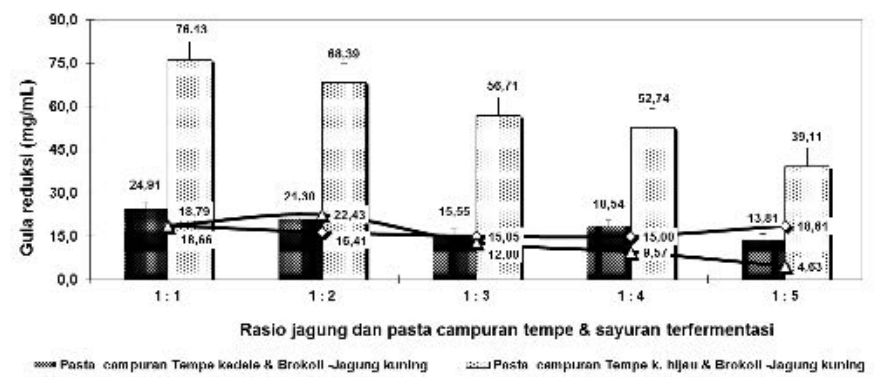

(a)

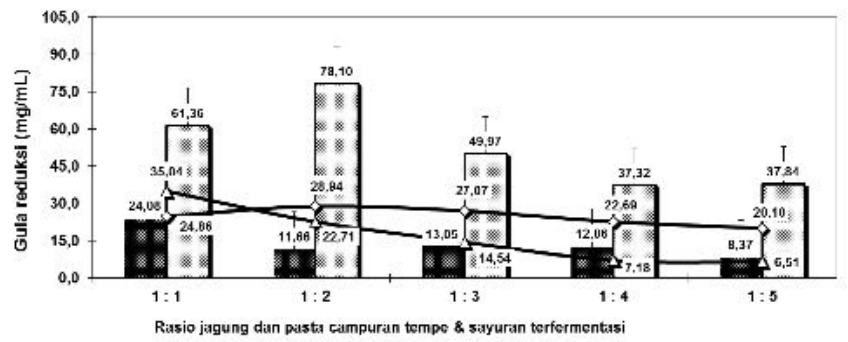

- Paste campuran Tempe kectele \& Brokoll Jagung puth Wasta campuran Tempe K. hllau \& Brokoll Jagung puth

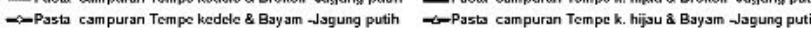
(b)

Figur 7. Hubungan antara nikstamal jagung kuning (a) dan nikstamal jagung putih (b), jenis pasta tempe \& sayuran dan rasio antara keduanya terhadap perolehan gula reduksi pada pasta fortifikan sebagai sumber asam folat alami untuk 'pangan pintar'.

Pengaruh formulasi terhadap komposisi gula reduksi

Gula reduksi pada pasta fortifikan merupakan parameter tersisanya gula-gula yang bersifat mereduksi yang tidak digunakan mikroba untuk metabolismenya pada sayuran terfermentasi. Penggunaan sukrosa dalam fermentasi sayuran terfermentasi oleh kultur kombucha adalah sebagai sumber carbon untuk menghasilkan asam folat, selain asam-asam organik yang lain dan polifenol sayuran. Dalam proses formulasi ini, gula reduksi juga di peroleh dari tempe melalui degradasi enzim amylase inokulum $R$. oligosporus $\mathrm{C}_{1}$ dan nikstamal jagung melalui pemecahan polisakarida (pati) baik melalui reaksi panas maupun enzimatik (secara alami oleh bakteri) selama proses perendaman dalam air dan perebusan dengan penambahan $\mathrm{Ca}(\mathrm{OH})_{2}$. Proses-proses ini dimungkinkan membentuk gula-gula yang bersifat mereduksi diantaranya adalah glukosa dan fruktosa (Belitz et al., 1999) menurut metode NelsonSomogyi. Masing-masing bahan akan saling berakumulasi sebagai pasta fortifikan dimana keberadaanya menjadi cukup penting oleh karena memberi rasa manis namun dengan kalori yang lebih rendah (sebagai glukosa dan fruktosa) dibandingkan penggunaan sukrosa pada aplikasi fortifikan. Semakin meningkatnya rasio nikstamal jagung pada pasta campuran tempe dan sayuran terfermentasi dapat menurunkan gula reduksi seperti ditunjukkan pada Figur $7 a$ dan $7 b$.

Penurunan gula reduksi diduga juga disebabkan terjadinya penguraian metabolit (asam-asam organik) dan akumulasinya dengan komponen sayuran terfermentasi (polifenol). Semakin tinggi rasio nikstamal jagung, menyebabkan penguraian gula reduksi yang semakin tinggi. Meskipun demikian telah terjadi peningkatan gula reduksi pada kondisi optimisasi proses formulasi dibandingkan dengan pasta campuran tempe dan sayuran terfermentasi tanpa penambahan nikstamal jagung. Berdasarkan ketersediaan tertinggi pasta fortifikan sebagai sumber kalori menggunakan jagung kuning dan jagung putih masing-masing dicapai pada kombinasi perlakuan jagung kuning dan jagung putih dengan pasta campuran tempe kacang hijau dan brokoli terfermentasi pada rasio 1:1 dan 1:2 yang menghasilkan pasta fortifikan dengan gula reduksi sebesar 76,13 dan $78,10 \mathrm{mg} / \mathrm{ml}$. Pada kondisi ini, penambahan nikstamal jagung kuning dan nikstamal jagung putih meningkatkan gula reduksi pasta fortifikan masing-masing sebesar 425,03 dan 438,62\% dibandingkan dengan gula reduksi awal pasta campuran tempe kacang hijau dan brokoli terfermentasi sebesar $14,5 \mathrm{mg} / \mathrm{ml}$.

Dari proses optimasi formulasi berdasarkan asam folat terbaik sebagai pasta fortifikan, dicapai pada penggunaan nikstamal jagung kuning dan nikstamal jagung putih masing-masing difortifikasikan pada pasta campuran tempe kacang hijau dengan brokoli terfermentasi pada rasio 5:1 masing-masing menghasilkan pasta fortifikan sebesar 561,91 dan $570,41 \mu \mathrm{g} / \mathrm{ml}$. Pada kondisi ini, penambahan nikstamal jagung kuning dan nikstamal jagung putih meningkatkan asam folat dan total padatan pasta fortifikan masingmasing sebesar 43,45 dan $45,62 \%$ serta 0,45 dan $7,67 \%$ dibandingkan dengan asam folat dan total padatan awal pasta campuran tempe kacang hijau dan brokoli 
terfermentasi, namun terjadi penurunan protein terlarut, total gula dan gula reduksi akibat penambahan nikstamal jagung kuning dan nikstamal jagung putih yang masingmasing sebesar 30,43 dan $15,22 \%$; 84,70 dan $81,67 \%$; 169,72 dan $160,96 \%$ dibandingkan dengan protein terlarut, total gula dan gula reduksi pasta campuran tempe kacang hijau dan brokoli terfermentasi awal sebelum adanya penambahan nikstamal jagung kuning dan nikstamal jagung putih. Figur $8 \mathrm{a}$ dan $8 \mathrm{~b}$ masingmasing memperlihatkan pasta fortifikan dari kombinasi nikstamal jagung kuning dan nikstamal jagung putih dengan pasta yang berasal dari campuran tempe kacang hijau dengan brokoli terfermentasi pada rasio 1:5.
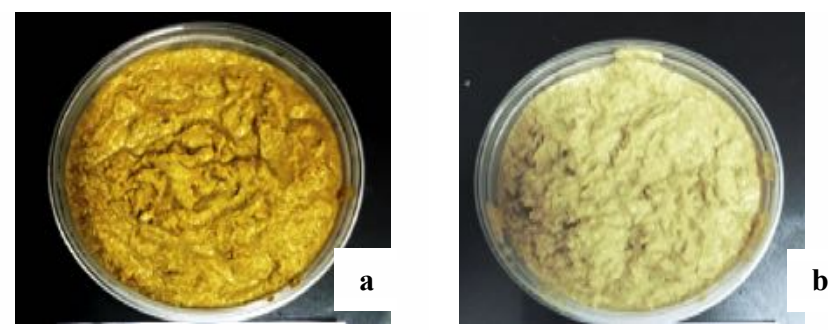

Figur 8. Pasta fortifikan kombinasi (a) jagung kuning dan (b) jagung putih (5 bagian) masing-masing dengan campuran tempe kacang hijau dan brokoli terfermentasi (1 bagian).
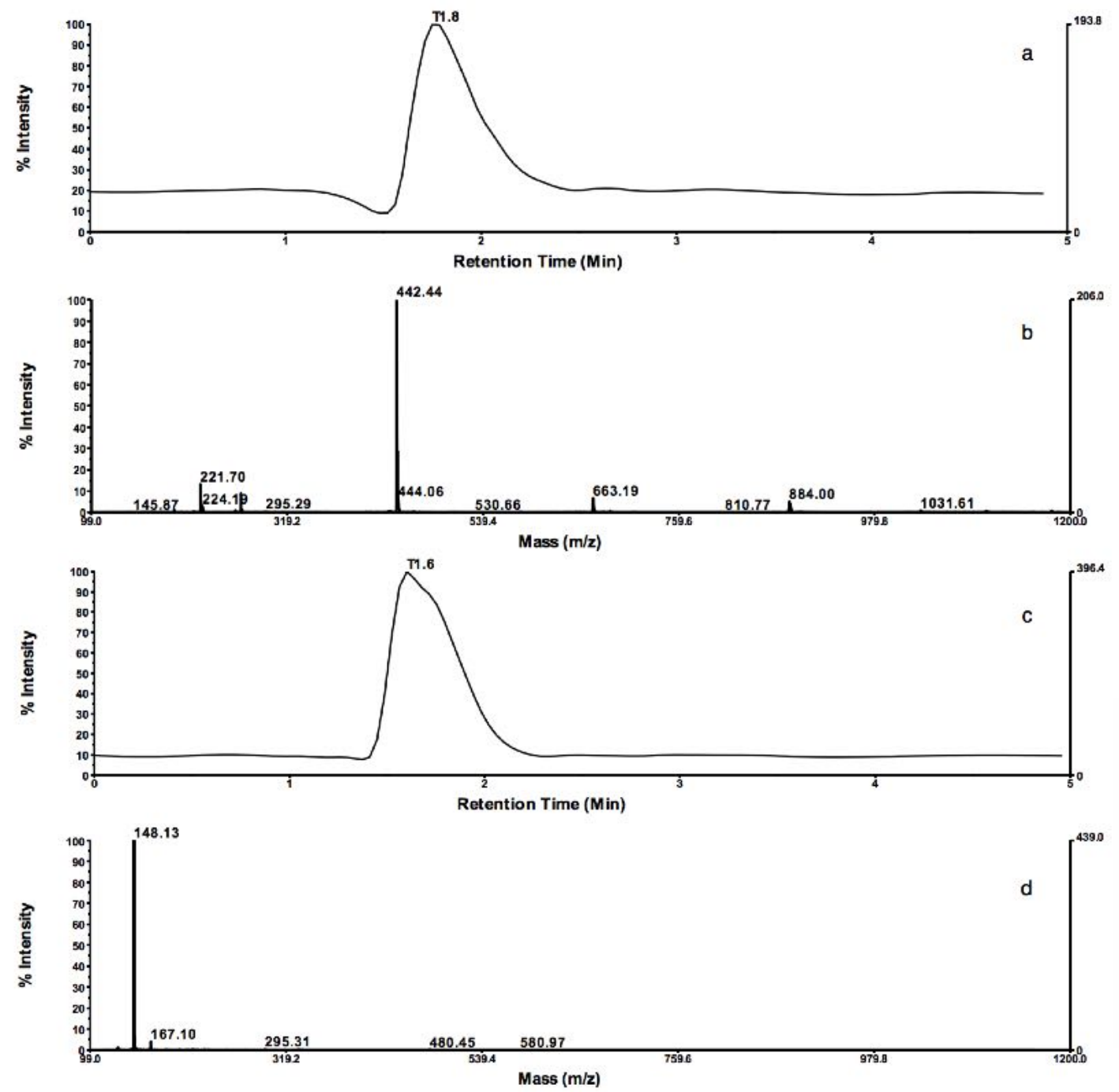

Identifikasi monomer asam folat dan asam glutamat melalui LCMS

Identifikasi monomer pada standar asam glutamat dilakukan oleh karena asam glutamat adalah bagian dari asam folat (Belitz and Grosch, 2002). Identifikasi terhadap standar asam folat diperoleh 1 peak kromatogram dengan waktu retensi masing-masing 0-5 menit yaitu $\mathrm{T} 1,8$ dengan relatif intensitas $100 \%$ dan mass spektra T 1,8 pada 99-1200 m/z yang didominasi monomer berberat molekul 442,44 Da, masing-masing seperti yang ditunjukkan pada Figur 9a dan 9b.

Identifikasi monomer standar asam glutamat diperoleh 1 peak kromatogram dengan waktu retensi masing-masing 0-5 menit yaitu $T$ 1,6 dengan relatif intensitas $100 \%$ dan mass spektra $T$ 1,6 pada $99-1200$ $\mathrm{m} / \mathrm{z}$ yang didominasi monomer berberat molekul 148,13 $\mathrm{Da}$, yang masing-masing seperti yang ditunjukkan pada Figur 10c dan 10d. Asam folat dan asam glutamat masing-masing diketahui berberat molekul 441 dan 148 Da (Belitz et al., 1999). Berdasarkan LCMS diketahui bahwa dimungkinkan suatu senyawa memperlihatkan perbedaan $\mathrm{BM}$ dimana kemungkinannya adalah sebagai $\mathrm{M}^{+}, \mathrm{M}+\mathrm{Na}^{+}, 2 \mathrm{M}^{++}$atau $2 \mathrm{M}^{+}+\mathrm{Na}^{+}$. Hal ini disebabkan oleh adanya ionisasi karena sensitifitas instrumen LCMS yang berkaitan dengan eluent yang digunakan.

Figur 9. (a) Kromatogram standar asam folat, (b) mass spektra standar asam asam folat dengan $\mathrm{T} 1.8$ pada mass spektra 99-1200 m/z; (c) kromatogram standar asam glutamat ; (d) mass spektra standar asam glutamat $T 1.6$ pada 99$1200 \mathrm{~m} / \mathrm{z}$. 

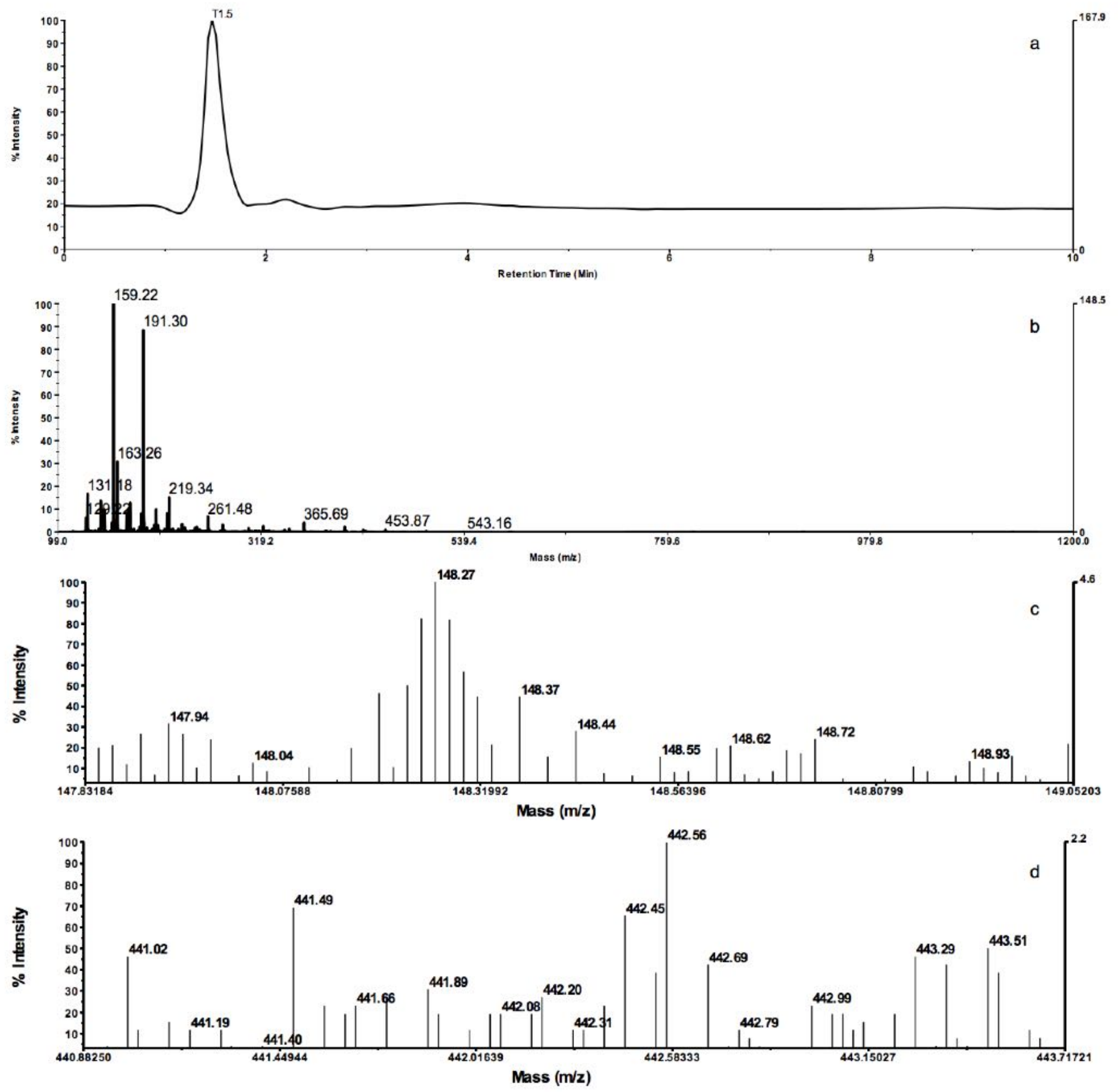

Figur 10. (a) Kromatogram nikstamal jagung kuning dari kondisi proses terbaik untuk formulasi pasta fortifikan dengan waktu retensi 0-10 menit (T) 1.5; (b) mass spektra antara 99-1200 m/z; (c) monomer asam glutamat pada mass spektra antara 147,43-149 m/z dari T 1,5 dan (d) monomer asam folat pada mass spektra antara 440-443 m/z dari T 1,5.

Kondisi operasi LC-MS adalah pada volume injeksi $5 \mu \mathrm{L}$, laju alir $0,1 \mathrm{ml} / \mathrm{menit}$ dengan eluent campuran metanol dan air pada rasio 80:20, menggunakan kolom C-8 (15 mm x 2 mm) (Eichhorn and Knepper, 2001).

Identifikasi monomer asam folat dan asam glutamat pada nisktamal jagung kuning

Pasta fortifikan terdiri dari nikstamal jagung kuning/nikstamal jagung putih (5 bagian) yang difortifikasikan pada pasta campuran tempe kacang hijau dan brokoli terfermentasi pada rasio 1:1 (1 bagian). Identifikasi monomer asam folat dan asam glutamat pada masing-masing bahan dilakukan melalui LCMS dengan spesifikasi perlakuan analisis spesifik pada setiap bahan.

Hasil identifikasi nikstamal jagung kuning dari perlakuan perebusan 60 menit, $\mathrm{Ca}(\mathrm{OH})_{2} 20 \%$ diperoleh kromatogram dengan 1 peak $(T 1,5)$ pada waktu retensi 0-10 menit seperti ditunjukkan pada Figur 10a. Pada mass spektra dari T 1,39 antara 99-1200 m/z pada Figur $10 \mathrm{~b}$ tidak memperlihatkan monomer asam glutamat meskipun diketahui bahwa intensitas relatif asam glutamat adalah sebesar $1,41 \%$, sedangkan asam folat tidak ditemukan pada kisaran mass spektra ini. Monomer asam glutamat baru tampak pada mass spektra antara 
147,43-149 m/z dengan berat molekul antara 147,94$148,93 \mathrm{Da}$. dengan intensitas relatif antara 1,18-0,81\%. Mass spektra ini didominasi oleh monomer dengan berat molekul 148,27 Da, dengan intensitas relatif 3,73\% seperti ditunjukkan pada Figur 10c. Hal yang sama tampak pada monomer asam folat sebagaimana ditunjukkan pada mass spektra antara 440-443 m/z yang menunjukkan monomer asam folat berberat molekul antara 441,02-443,51 Da, dengan intensitas relatif antara 4,93-11,82\%. Mass spektra ini didominasi oleh monomer dengan berat molekul 442,56 Da, dengan intensitas relatif $25,51 \%$ seperti ditunjukkan pada Figur 10d.

Identifikasi monomer asam folat dan asam glutamat pada nikstamal jagung putih

Hasil identifikasi nikstamal jagung putih dari perlakuan terbaik (perebusan 30 menit, $\mathrm{Ca}(\mathrm{OH})_{2} 30 \%$ ) diperoleh kromatogram dengan 1 peak $(T 1,5)$ pada waktu retensi 0-10 menit (data tidak ditampilkan). Pada mass spektra dari T 1,5 antara 99-1200 m/z tidak memperlihatkan monomer asam glutamat, namun tampak jelas pada mass spektra antara 147,39-148,96 $\mathrm{m} / \mathrm{z}$ dengan berat molekul antara 147,92-148,86 Da, dengan intensitas relatif antara $0,71-1,8 \%$. Mass spektra ini didominasi oleh monomer dengan berat molekul 148,32 $\mathrm{Da}$, dengan intensitas relatif $1,8 \%$. Monomer asam folat berberat molekul 441,94 Da, ditemukan dengan intensitas relatif $0,12 \%$ pada kisaran 99-1200 m/z (data tidak ditampilkan), namun tampak lebih jelas pada mass spektra antara 440,81-443,38 m/z dengan berat molekul antara 440,92-443, 23 Da, dengan intensitas relatif antara 0,43-2,29\%. Mass spektra ini didominasi oleh monomer dengan berat molekul 441,73 Da dengan intensitas relatif 100\%.

Identifikasi monomer asam folat dan asam glutamat pada pasta $1: 1$

Hasil identifikasi monomer pada pasta campuran tempe kacang hijau dengan brokoli terfermentasi pada rasio 1 bagian tempe kacang hijau dengan 1 bagian brokoli terfermentasi, diperoleh 1 peak $(T 1,6)$ pada waktu retensi 0-10 menit dengan relatif intensitas 100\%. Mass spektra T 1,6 pada 113-224 m/z memperlihatkan dominasi monomer berberat molekul 132,5, 166,41 dan 182,41 Da dengan waktu retensi berturut-turut 40,04, 100 dan 182,41 Da atau dominasi pada monomer berberat molekul 166,41 yang diduga sebagai asam amino dari tempe (data tidak ditampilkan). Monomer dengan berat molekul yang serupa berturut-turut adalah $166,59,166,77,166,96$ dan 167,40 Da dengan intensitas relatif berturut-turut $7,14,9,01,5,11$ dan $7,1 \%$. Terhadap monomer dengan dugaan sebagai asam folat ditunjukkan pada senyawa berberat molekul 433,63 dan 443,50 Da dengan intensitas relatif masing-masing 0,04 dan $0,07 \%$. Hal ini diduga melalui proses homogenisasi pada kecepatan putar $8000 \mathrm{rpm}$ selama 30 menit pada tempe dan bayam terfermentasi memungkinkan terjadinya pecahan asam folat, meskipun analisis menunjukkan optimisasi pada perlakuan ini namun sebagai total asam folat dari seluruh derivatnya. Mass spektra antara 113-224 $\mathrm{m} / \mathrm{z}$ memperlihatkan keberadaan monomer asam glutamat dengan berat molekul 148,33 Da dengan intensitas relatif sebesar $0,59 \%$. Keberadaan asam glutamat dimungkinkan oleh karena merupakan bagian dari asam folat selain PABA dan pteridin (Belitz et al., 1999), selain berada sebagai monomer tunggal pada tempe atau brokoli terfermentasi.

\section{Kesimpulan}

Optimasi formula dicapai pada kombinasi pasta campuran tempe kacang hijau dan brokoli masingmasing dengan nikstamal jagung kuning dan jagung putih pada rasio 1:5 yang terbukti dapat meningkatkan asam folat dan total padatan pasta, namun dapat menurunkan protein terlarut, total gula dan gula reduksi. Identifikasi monomer asam folat dan asam glutamat nikstamal jagung kuning dan nikstamal jagung putih yang digunakan masing-masing menunjukkan dominasi monomer asam folat berberat molekul yang variatif dan juga dengan intensitas relatif yang bervariasi.

\section{Ucapan Terimakasih}

Terima kasih ditujukan kepada Kemenristekdikti melalui Program Insentif Riset Sistem Inovasi Nasional (INSINAS) tahun 2018, atas dukungan penelitian ini pada Program INSINAS Riset Pratama Individu pada Bidang Riset Pengembangan Pangan Fungsional Berbasis Sumberdaya Lokal.

\section{Daftar Pustaka}

Belitz, H.D., Grosch, W., Schieberle, P. 1999. Food chemistry. ed. Springer-Verlag. Berlin Heidelberg.

Crécy-Lagard, V. de, Yacoubi, B. El, la Garza, R.D. de, Noiriel, A., Hanson, A.D. 2007. Comparative genomics of bacterial and plant folate synthesis and salvage: predictions and validations. BMC genomics 8(1): 245. BioMed Central. DOI:10.1186/1471-2164-8-245

Dubois, M., Gilles, K.A., Hamilton, J.K., Rebers, P.A.t, Smith, F. 1956. Colorimetric method for determination of sugars and related substances. Analytical chemistry 28(3): 350-356.

Eichhorn, P., Knepper, T.P. 2001. Electrospray ionization mass spectrometric studies on the amphoteric surfactant cocamidopropylbetaine. Journal of mass spectrometry 36(6): 677-684. Wiley Online Library. DOI:10.1002/jms.170

Hauser, P.M., Macreadie, I.G. 2006. Isolation of the Pneumocystis carinii dihydrofolate synthase gene and functional complementation in Saccharomyces cerevisiae. FEMS microbiology letters 256(2): 244250. Blackwell Publishing Ltd Oxford, UK. DOI:10.1111/j.1574-6968.2006. 00118.x

Malbaša, R., Lončar, E., Djurić, M. 2008. Comparison of the products of Kombucha fermentation on sucrose and molasses. Food chemistry 106(3): 1039-1045. Elsevier. DOI:10.1016/j.foodchem. 2007.07.020 
Quinlivan, E.P., Roje, S., Basset, G., Shachar-Hill, Y., Gregory, J.F., Hanson, A.D. 2003. The folate precursor $\mathrm{p}$-aminobenzoate is reversibly converted to its glucose ester in the plant cytosol. Journal of Biological Chemistry 278(23): 20731-20737. ASBMB. DOI:10.1074/jbc.M302894200

Rooney, L.W., Serna-Saldivar, S.O. 1987. Food uses of whole corn and dry-milled fractions. American Association of Cereal Chemists, Inc.

Ruengsitagoon, W., Hattanat, N. 2012. Simple spectrophotometric method for determination of folic acid. The 4th Annual Northeast Pharmacy Research Conference of "Pharmacy Profession in Harmony.

Susilowati, A., Aspiyanto, Maryati, Y., Melanie, H., Lotulung, P.D. 2017. Potency of microfiltration membrane process in purifying broccoli (Brassica oleracea $L$.) fermented by lactic acid bacteria (LAB) as functional food. AIP Conference Proceedings. Vol. 1803, p. 20028. AIP Publishing. DOI:10.1063/1.4973155

Susilowati, A., Iskandar, J.M., Melanie, H., Maryati, Y., Lotulung, P.D., Aryani, D.G. 2015. Pengembangan Konsentrat Sayuran Hijau dan Kacang-kacangan Terfermentasi pada jagung (Zea mays L.) pramasak sebagai sumber asam Folat untuk formula pangan pintar. Laporan Hasil Penelitian, Program Tematik, Kedeputian IPT, Tahun Anggaran.
Susilowati, A., Melanie, H. 2017. Characterization of fermented broccoli (Brassica oleracea L.) and spinach (Amaranthus sp.) produced using microfiltration membrane as folic acid source for smart food formula. MATEC Web of Conferences. Vol. 101, p. 1005. EDP Sciences. DOI:10.1051/ matecconf/201710101005

Susilowati, A., Melanie, H., Maryati, Y. 2010. Green tea (Camellia assamica) concentrate as a source of Ltheanine used in kombucha fermentation for relaxation drink. Menara Perkebunan 78(2): 75-82. Unit Penelitian Bioteknologi Perkebunan. DOI: DOI:10.22302/iribb.jur.mp.v78i2.67

Syarief, R., Hermanianto, J., Hariyadi, P., Wiriatmadja, S. 1999. Wacana Tempe Indonesia. Universitas Katolik Widya Mandala Press. Surabaya.

Ural, S.H. 2008. Folic acid and pregnancy. Kid's Health.

Vora, A., Riga, A., Dollimore, D., Alexander, K.S. 2002. Thermal stability of folic acid. Thermochimica Acta 392 209-220. Elsevier. DOI:10.1016/ S00406031(02)00103-X 